\title{
Linear electrooptic effect in doped KuP crystals
}

\author{
K B R VARMA**, K V RAMANAIAH and K VEERABHADRA RAO* \\ Department of Physics, PSG College of Technology, Coimbatore 641004 , India \\ *Advanced Centre for Materials Science, Indian Institute of Technology, Kanpur 208 016, India. \\ * Laser Communication Laboratory, Department of Electrical Engineering, Indian Institute \\ of Technology, Madras 600 036, India
}

MS received 17 May 1982; revised 13 August 1982

\begin{abstract}
The dispersion of half wave voltages with wave length and temperature of potassium dihydrogen ortho phosphate (KDP) crystals with additives and dopants like borax, nickel phosphate, manganese phosphate, sodium dihydrogen orthophosphate and potassium arsenate were determined. The refractive index for all the above crystals were found by the modified Rayleigh's refractometer method. The linear electrooptic coefficients were calculated at various wavelengths of light. The variation of half wave voltage was also studied as a function of conventration of the dopant.
\end{abstract}

Keywords. Electrooptic effect; KDP; half wave voltage; dispersion of electrooptic coefficients; dopants.

\section{Introduction}

The electrooptic properties of KDP and Ammonium dihydrogen phosphate (ADP) crystals have been extensively studied. Vlokh $e t$ al (1971) reported the $r_{63}$ values of ADP and KDP at high temperature and at wavelength of $4500^{\circ} \mathrm{A}$. Veerabhadra Rao (1972) studied the dispersion of electrooptic coefficients of ADP and KDP for different orientations. Onaka and Ito (1977) studied the electrooptic effect and vacuum ultraviolet absorption of these crystals while Milek and Neuberger (1972) reviewed their linear electrooptic properties. However, no systematic study of the electrooptic effect has been made either in mixed crystals of KDP and sodium dihydrogen orthophosphate $\left(\mathrm{NaH}_{2} \mathrm{PO}_{4}\right)$, KDP and potassium arsenate or KDP with dopants such as nickel phosphate $\left(\mathrm{NiPO}_{4}\right)$ and manganese phosphate $\left(\mathrm{Mn}_{3}\left(\mathrm{PO}_{4}\right)_{2}\right)$. No attempt has been made to study the effect of growth aids like borax $\left(\mathrm{Na}_{2} \mathrm{~B}_{4} \mathrm{O}_{7} .10 \mathrm{H}_{2} \mathrm{O}\right)$ on the electrooptic properties of KDP. Hence the present study was undertaken.

Initially, experiments were carried out on pure KDP crystals to effect a comparative study of the electrooptic coefficients between KDP and KDP crystals with additives and dopants. The crystals required were grown by slow evaporation (Holden's rotary crystalizer) technique. The details regarding effects of growth-aiding materials and dopants on the growth habit and growth rates of KDP crystals have already been reported (Ramanaiah and Varma 1982). The crystals of KDP grown with various dopants were of fairly large size, good optical quality and free from strains. 

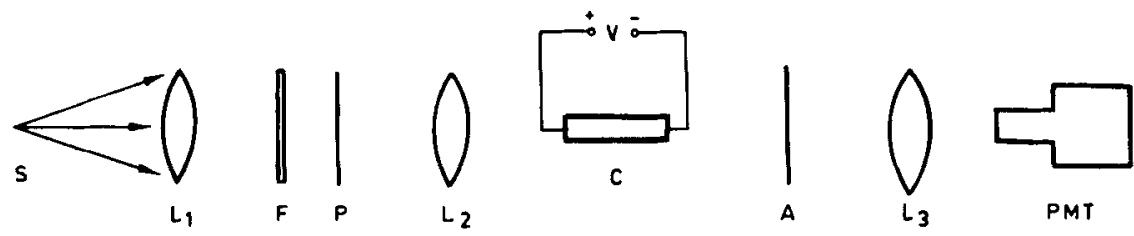

$S$ - SOURCE OF WHITE LIGHT

$L_{2}, L_{3}$ - CONVERGING LENSES

LI - COLLIMATING LENS

F - OPTICAL FILTER

P - POLARIZER

C - CRYSTAL UNDER INVESTIGATION

A - ANALYZER

PMT - PHOTO MULTIPLIER TUBE

Figure 1. Optical arrangement to measure half-wave voltages of crystals.

\section{Experimental arrangement}

The optical arrangement for studying the dispersion of electrooptic coefficient $r_{63}$ with both temperature and wavelength is schematically shown in figure $1 . S$ is a source of white light, $L_{1}$, a collimating lens and $F$ an interference filter, $P$ and $A$ are two polarizers, to polarize and analyse the light. $L_{2}$ is another lens to focus the light on the experimental crystal $C$. The light from the analyzer falls on the photomultiplier tube which responds to the variations of light intensity from the crystal.

To measure the halfwave voltage of the crystal at different temperatures, a cell was designed. The dimensions of the glass cell were $4.5 \times 3 \times 2 \mathrm{~cm}^{3}$. The present study is confined to the measurement of electrooptic coefficients in the longitudinal mode. Tin oxide-coated glass plates were used as electrodes. One of the electrodes was fixed to one wall of the cell (in the direction of the propagation of light) and the other was free to move within the cell. The crystal was placed with its $Z$-axis (optic axis) perpendicular to the electrode surface between the two electrodes and the cell was packed with spacers made of hylam to facilitate passage of light. Contacts were fixed on the electrode surfaces and leads were taken from these contacts to a high voltage power supply. The power supply was built with a 230 to $20,000 \mathrm{~V}$ step-up transformer. The rectifier system was constructed with BY 127 diodes connected in series.

The crystal cell was filled with silicone oil, to protect the crystal surfaces from moisture, ensure uniform heating of crystal and to safeguard against flashover. The cell was heated by a flat heater placed below it. The temperature of the oil in the cell was sensed and controlled $\left( \pm 0.1^{\circ} \mathrm{C}\right)$ by a jumo contact thermometer coupled to an electronic relay unit.

The filter holder, polarizer, analyzer, the crystal cell and the photomultiplier tube (PMT) (RCA 931A) were mounted on an optic bench and were aligned using helium-neon laser. The polarizer's pass direction was kept vertical and the analyser was crossed with respect to the polarizer for extinction of light. The laser was then replaced by the halogen lamp. Adjustments were made to obtain a symmetric optic figure on the aperture of the photomultiplier tube. PMT was adjusted so that the central spot of the cross of the optic figure coincides with the centre of its aperture. This ensured that the light passing along the optic axis of the crystal is incident on it, the output of which was fed to a vacuum tube voltmeter. The voltage applied to the crystal was gradually increased and the corresponding change in intensity of light was registered by the PMT.

The voltage corresponding to the maximum intensity was determined by plotting a graph between the applied voltage and transmitted intensity of light. The voltage corresponding to the peak in the graph is termed as half-wave voltage. 


\section{Results}

\subsection{Dispersion of electrooptic coefficients of KDP with wavelength and temperature}

In order to compare the halfwave voltages and electrooptic coefficients of KDP and KDP with additives, experiments were initially carried out on pure KDP crystals. In the present study, the direction of the applied electric field and the direction of propagation of light are along [001] of the crystal. A typical curve showing the variation of transmitted intensity as a function of applied DC voltage at $4047 \AA$ and room temperature $\left(30^{\circ} \mathrm{G}\right)$ is shown in figure 2. Similar curves were obtained at 4358 and $5770 \AA$ and at different temperatures. The voltage corresponding to the maximum transmitted intensity is termed as the half-wave voltage $V_{\pi}$. This value is substituted in the formula $r_{63}=\lambda / 2 n_{0}^{3} V_{\pi}$ to obtain the unclamped (low frequency) electrooptic coefficient $r_{63}$. The refractive indices of all the crystals used were determined by a modified Rayleigh's refractometer method (Narasimhamurthy, unpublished). The $n_{0}$ values obtained for KDP and KDP with dopants and additives were almost the same. These values were also verified with those of KDP given in literature (Vishnevskii and Stefanskii 1972) and showed good agreement (table 1). As the temperature variation of $n_{0}$ for KDP is negligibly small, the same values are taken for the other temperatures also.

The values of measured half-wave voltages and calculated $\gamma_{63}$ coefficients for KDP at various wavelengths and temperatures are given in table 2 . The values of half-wave voltages and $r_{63}$ coefficients at 4358 and $5770 \AA$ were in good agreement with those given for KDP in the literature (Milek and Neuburger 1972).

Figure 3 shows the variation of half-wave voltage with wavelength of light at different temperatures. The results indicate that half-wave voltage of KDP increases linearly with increase in wavelength and temperature. The small discrepancy in the values is due to the limitation of the experimental technique.

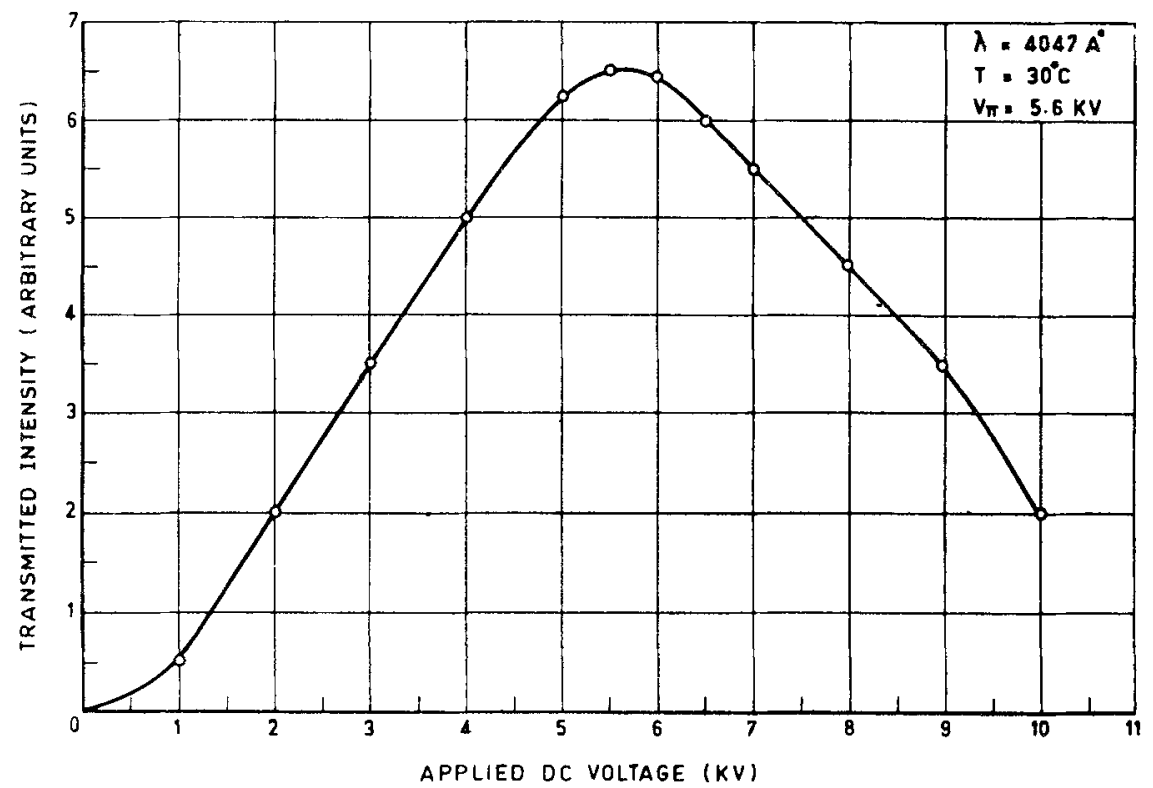

Figure 2. Variation of transmitted intensity with applied DC voltage for KDP. 
Table 1. Refractive indices of KDP.

\begin{tabular}{ccc} 
Wavelength & \multicolumn{2}{c}{$n_{0}$ at $25^{\circ} \mathrm{C}$} \\
\cline { 2 - 3 }$(\AA)$ & $\begin{array}{c}\text { Present } \\
\text { study }\end{array}$ & Literature \\
\hline 4047 & 1.523 & 1.5235 \\
4358 & 1.520 & 1.5200 \\
5770 & 1.510 & 1.5102 \\
\hline
\end{tabular}

Table 2. Half-wave voltages and $r_{63}$ (unclamped) coefficients for KDP.

\begin{tabular}{|c|c|c|c|c|c|}
\hline \multirow{2}{*}{$\begin{array}{l}\text { Wavelength } \\
\text { ( ̊) }\end{array}$} & \multirow{2}{*}{$\begin{array}{c}\text { Temperature } \\
\left({ }^{\circ} \mathrm{C}\right)\end{array}$} & \multicolumn{2}{|c|}{$V_{n}(\mathrm{kV})$} & \multicolumn{2}{|c|}{$\tau_{63} \times 10^{-12} \mathrm{~m} / \mathrm{v}$} \\
\hline & & $\begin{array}{l}\text { Present } \\
\text { study }\end{array}$ & Literature & $\begin{array}{r}\text { Present } \\
\text { study }\end{array}$ & Literature \\
\hline \multirow{4}{*}{4047} & 30 & 5.6 & - & 10.21 & - \\
\hline & 35 & 6.0 & . & 9.53 & - \\
\hline & 40 & 6.5 & . & 8.80 & - \\
\hline & 30 & 6.1 & 6.04 & 10.17 & 10.27 \\
\hline \multirow[t]{2}{*}{4358} & 35 & 6.5 & - & 9.54 & - \\
\hline & 40 & 7.0 & - & 8.86 & - \\
\hline \multirow{3}{*}{5770} & 30 & 8.2 & 8.17 & 10.21 & 10.25 \\
\hline & 35 & 8.6 & - & 9.74 & - \\
\hline & 40 & 9.3 & - & 9.01 & - \\
\hline
\end{tabular}

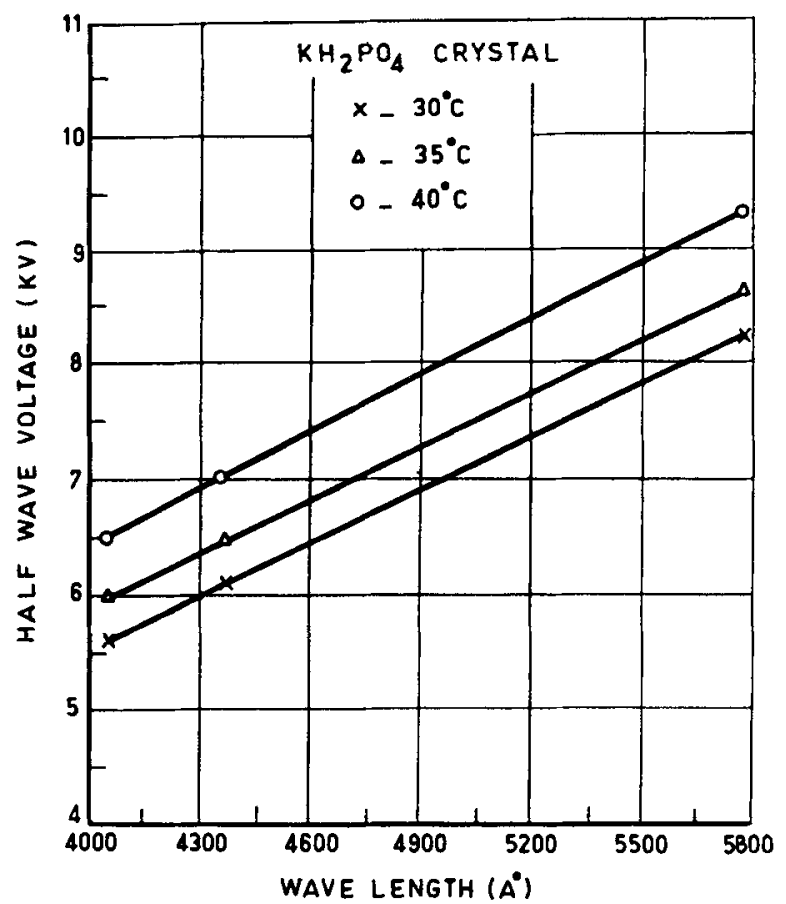

Figure 3. Variation of half-wave voltage as a function of wavelength for KDP. 


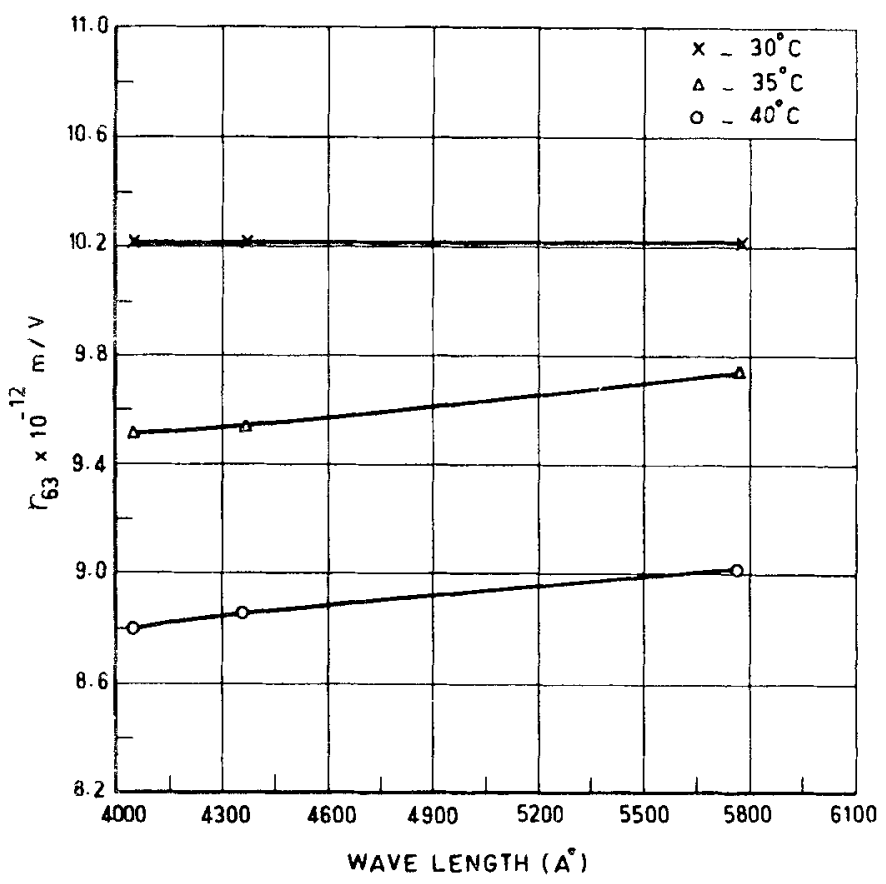

Figure 4. Dispersion of $r_{63}$ as a function of waveiength for KDP.

Figure 4 represents the dispersion of $r_{63}$ with wavelength at various temperatures. The electrooptic coefficient $r_{63}$ decreases with increase in temperature and increases with increase in wavelength. These results follow the same course as those in the literature for ADP (Milek and Neuberger 1972).

\subsection{Electrooptic effect in KDP with borax}

Borax has a remarkable effect on the solubility and growth characteristics of KDP (Ramanaiah and Varma 1982). To see whether the addition of borax alters the half-wave voltage of KDP, experiments were carried out and the results are presented below.

The variations of transmitted intensity with applied DC voltage at various wavelengths and temperatures for KDP crystals with $0.05,0.075$ and $0.1 \mathrm{M}$ borax is similar to that of pure KDP, as represented in figure 2 .

The trend in the variation of half-wave voltage with wavelength at different temperatures is similar to that of KDP crystals. table 3 shows that $r_{63}$ increases with increase in wavelength and decreases with increase in temperature. Further, the $r_{63}$ value decreases with increasing concentrations of borax in KDP. Since the dielectric constant is directly proportional to $r_{i j}$ (Kaminow and Turner 1966) the trend observed in the $r_{i j}$ values must also be reflected in the dielectric constants of these crystals. To verify this fact, dielectric constants of these crystals have been determined.

Figure 5 shows the variation of the dielectric constant $\varepsilon_{c}$ (along $Z$ axis) and $\varepsilon_{a}$ (perpendicular to $Z$ axis) with temperature for the crystals of KDP, KDP with 0.05 and $0.075 \mathrm{M}$ 
Table 3. Half wave voltages and $r_{63}$ (unclamped) coefficients for doped KDP crystals.

\begin{tabular}{|c|c|c|c|c|}
\hline Crystal & $\begin{array}{c}\text { Wavelength } \\
(\AA)\end{array}$ & $\begin{array}{l}\text { Temperature } \\
\left({ }^{\circ} \mathbf{C}\right)\end{array}$ & $\underline{V}_{\pi}(k V)$ & $763 \times 10^{-12} \mathrm{~m} / \mathrm{v}$ \\
\hline \multirow{4}{*}{$\begin{array}{l}\text { KDP + } \\
0.05 \mathrm{M} \\
\text { borax }\end{array}$} & 4047 & $\begin{array}{l}30 \\
35 \\
40\end{array}$ & $\begin{array}{l}6.0 \\
6.5 \\
7.0\end{array}$ & $\begin{array}{l}9.54 \\
8.80 \\
8.17\end{array}$ \\
\hline & 4358 & $\begin{array}{l}30 \\
35 \\
40\end{array}$ & $\begin{array}{l}6.3 \\
6.75 \\
7.5\end{array}$ & $\begin{array}{l}9.85 \\
9.19 \\
8.27\end{array}$ \\
\hline & 5770 & $\begin{array}{l}30 \\
35 \\
40\end{array}$ & $\begin{array}{l}8.5 \\
8.8 \\
9.3\end{array}$ & $\begin{array}{l}9.85 \\
9.52 \\
9.01\end{array}$ \\
\hline & 4047 & $\begin{array}{l}30 \\
35 \\
40\end{array}$ & $\begin{array}{l}6.5 \\
7.0 \\
7.5\end{array}$ & $\begin{array}{c}8.8 \\
8.17 \\
7.63\end{array}$ \\
\hline \multirow[t]{3}{*}{$\begin{array}{l}\text { KDP + } \\
0.075 \mathrm{M} \\
\text { borax }\end{array}$} & 4358 & $\begin{array}{l}30 \\
35 \\
40\end{array}$ & $\begin{array}{l}6.75 \\
7.25 \\
7.25\end{array}$ & $\begin{array}{c}9.19 \\
8.55 \\
8.0\end{array}$ \\
\hline & 5770 & $\begin{array}{l}30 \\
35 \\
40\end{array}$ & $\begin{array}{c}9.0 \\
9.5 \\
10.0\end{array}$ & $\begin{array}{l}9.31 \\
8.82 \\
8.33\end{array}$ \\
\hline & 4047 & $\begin{array}{l}30 \\
35 \\
40\end{array}$ & $\begin{array}{l}7.0 \\
7.4 \\
7.8\end{array}$ & $\begin{array}{l}8.17 \\
7.78 \\
7.34\end{array}$ \\
\hline \multirow[t]{3}{*}{$\begin{array}{l}\text { KDP + } \\
0.1 \mathrm{M} \\
\text { borax }\end{array}$} & 4358 & $\begin{array}{l}30 \\
35 \\
40\end{array}$ & $\begin{array}{l}7.3 \\
7.8 \\
8.5\end{array}$ & $\begin{array}{l}8.49 \\
7.95 \\
7.29\end{array}$ \\
\hline & 5770 & $\begin{array}{l}30 \\
35 \\
40\end{array}$ & $\begin{array}{c}9.7 \\
10.2 \\
10.8\end{array}$ & $\begin{array}{l}8.64 \\
8.21 \\
7.76\end{array}$ \\
\hline & 4047 & $\begin{array}{l}30 \\
35 \\
40\end{array}$ & $\begin{array}{l}6.0 \\
6.5 \\
7.0\end{array}$ & $\begin{array}{l}9.54 \\
8.86 \\
8.17\end{array}$ \\
\hline \multirow[t]{3}{*}{$\begin{array}{l}\mathrm{KDP}+ \\
1 \% \mathrm{ADP} .\end{array}$} & 4358 & $\begin{array}{l}30 \\
35 \\
40\end{array}$ & $\begin{array}{l}6.5 \\
7.0 \\
7.5\end{array}$ & $\begin{array}{l}9.54 \\
8.86 \\
8.27\end{array}$ \\
\hline & 5770 & $\begin{array}{l}30 \\
35 \\
40\end{array}$ & $\begin{array}{l}8.5 \\
9.0 \\
9.5\end{array}$ & $\begin{array}{l}9.85 \\
9.31 \\
8.82\end{array}$ \\
\hline & 4047 & $\begin{array}{l}30 \\
35 \\
40\end{array}$ & $\begin{array}{c}4.25 \\
4.5 \\
5.0\end{array}$ & $\begin{array}{l}14.46 \\
12.72 \\
11.44\end{array}$ \\
\hline \multirow[t]{3}{*}{$\begin{array}{l}\mathrm{KDP}+ \\
0.1 \% \\
\mathrm{NiPO}_{4}\end{array}$} & 4358 & $\begin{array}{l}30 \\
35 \\
40\end{array}$ & $\begin{array}{c}4.8 \\
5.2 \\
5.75\end{array}$ & $\begin{array}{l}12.92 \\
11.93 \\
10.79\end{array}$ \\
\hline & 5770 & $\begin{array}{l}30 \\
35 \\
40\end{array}$ & $\begin{array}{c}6.75 \\
7.0 \\
7.75\end{array}$ & $\begin{array}{c}12.4 \\
11.96 \\
10.81\end{array}$ \\
\hline & 4047 & $\begin{array}{l}30 \\
35 \\
40\end{array}$ & $\begin{array}{l}6.6 \\
7.0 \\
7.5\end{array}$ & $\begin{array}{l}8.67 \\
8.17 \\
7.63\end{array}$ \\
\hline $\begin{array}{l}\mathrm{KDP}+ \\
0.2 \% \\
\mathrm{NiPO}_{4}\end{array}$ & 4358 & $\begin{array}{l}30 \\
35 \\
40\end{array}$ & $\begin{array}{l}7.0 \\
7.5 \\
8.0\end{array}$ & $\begin{array}{l}8.86 \\
8.27 \\
7.75\end{array}$ \\
\hline
\end{tabular}


Table 3. (Contd.)

\begin{tabular}{|c|c|c|c|c|}
\hline Crystal & $\begin{array}{c}\text { Wavelength } \\
(\AA)\end{array}$ & $\begin{array}{c}\text { Temperature } \\
\left({ }^{\circ} \mathrm{C}\right)\end{array}$ & $\underline{V}_{n}(k V)$ & $r_{63} \times 10^{-12} \mathrm{~m} / \mathrm{v}$ \\
\hline $\begin{array}{l}\mathrm{KDP}+ \\
0.2 \% \\
\mathrm{NiPO}_{4}\end{array}$ & 5770 & $\begin{array}{l}30 \\
35 \\
40\end{array}$ & $\begin{array}{c}9.0 \\
9.5 \\
10.3\end{array}$ & $\begin{array}{l}9.31 \\
8.82 \\
8.13\end{array}$ \\
\hline \multirow{3}{*}{$\begin{array}{l}\mathrm{KDP}+ \\
0.025 \% \\
\mathrm{Mn}_{3}\left(\mathrm{PO}_{4}\right)_{2}\end{array}$} & 4047 & $\begin{array}{l}30 \\
35 \\
40\end{array}$ & $\begin{array}{c}6.0 \\
6.5 \\
6.75\end{array}$ & $\begin{array}{c}5.4 \\
8.80 \\
8.48\end{array}$ \\
\hline & 4358 & $\begin{array}{l}30 \\
35 \\
+0\end{array}$ & $\begin{array}{l}6.3 \\
6.7 \\
7.0\end{array}$ & $\begin{array}{l}9.84 \\
9.26 \\
8.86\end{array}$ \\
\hline & 5770 & $\begin{array}{l}30 \\
35 \\
40\end{array}$ & $\begin{array}{l}8.0 \\
8.5 \\
9.3\end{array}$ & $\begin{array}{c}10.47 \\
9.85 \\
9.0\end{array}$ \\
\hline \multirow{3}{*}{$\begin{array}{l}\mathrm{KDP}+ \\
1 \% \\
\mathrm{NaH}_{2} \mathrm{PO}_{4}\end{array}$} & $+04 i$ & $\begin{array}{l}30 \\
35 \\
40\end{array}$ & $\begin{array}{l}6.2 \\
6.7 \\
7.0\end{array}$ & $\begin{array}{l}9.23 \\
8.54 \\
8.17\end{array}$ \\
\hline & +358 & $\begin{array}{l}30 \\
35 \\
10\end{array}$ & $\begin{array}{l}6.7 \\
7.2 \\
7.5\end{array}$ & $\begin{array}{l}9.26 \\
8.61 \\
8.27\end{array}$ \\
\hline & 5770 & $\begin{array}{l}30 \\
35 \\
10\end{array}$ & $\begin{array}{c}8.7 \\
9.3 \\
10.2\end{array}$ & $\begin{array}{l}9.63 \\
9.01 \\
8.21\end{array}$ \\
\hline \multirow{3}{*}{$\begin{array}{l}\mathrm{KDP}+0.5 \% \\
\text { potassium } \\
\text { arsenate }\end{array}$} & $404 \%$ & $\begin{array}{l}30 \\
35 \\
+0\end{array}$ & $\begin{array}{l}6.0 \\
6.0 \\
6.0\end{array}$ & $\begin{array}{l}9.54 \\
9.54 \\
9.54\end{array}$ \\
\hline & +358 & $\begin{array}{l}30 \\
35 \\
40\end{array}$ & $\begin{array}{l}6.5 \\
6.5 \\
6.5\end{array}$ & $\begin{array}{l}9.54 \\
9.54 \\
9.54\end{array}$ \\
\hline & 5770 & $\begin{array}{l}30 \\
35 \\
40\end{array}$ & $\begin{array}{l}8.25 \\
8.75 \\
8.7\end{array}$ & $\begin{array}{l}10.15 \\
9.57 \\
9.41\end{array}$ \\
\hline
\end{tabular}

borax. The dielectric constants of these samples were calculated by measuring the capacitance at $1 \mathrm{kHz}$ using a digital LCR bridge. The results obtained for KDP were compared with values published earlier (Milek and Neuberger 1972).

The small divergence in these results from earlier studies may be due to the slightly higher temperature $\left(30^{\circ} \mathrm{C}\right)$ at which the present study was made. It was found that the crystals of KDP with borax have low dielectric constants as compared to that of pure $\mathrm{KDP}$ crystals. These results agree with the observed values $r_{63}$ and thus confirm the validity of the results obtained for $\gamma_{63}$ and $V_{\pi}$. Hence, it may be concluded that growth of crystals with addition of borax to KDP has some advantages such as increased growth rate with good optical quality, increase in the hardness and reduction in hygroscopicity. The only undesirable fact is that the half-wave voltages for these crystals are higher. This would necessitate higher voltages for modulation and switching purposes, which is undesirable from the device point of view. 


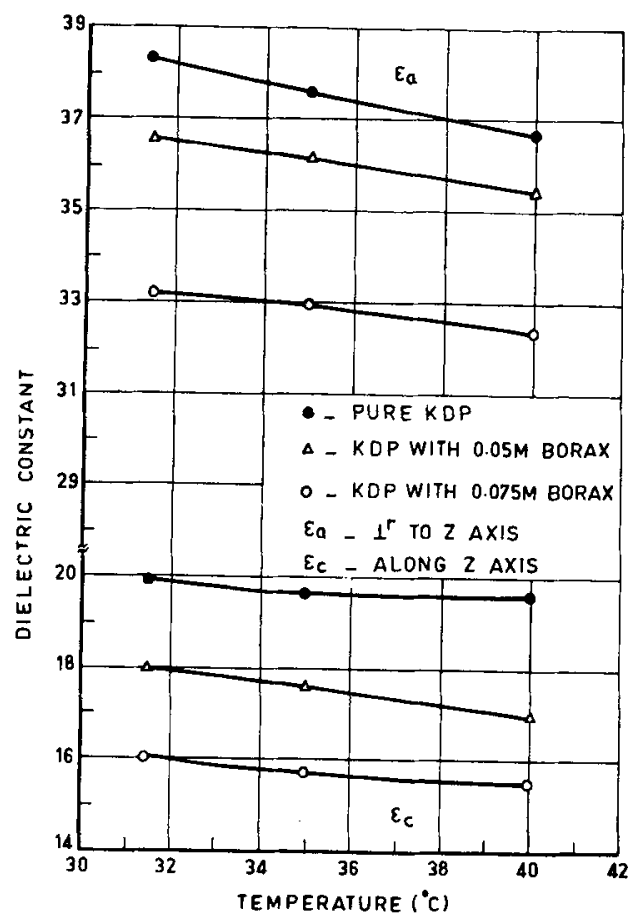

Figure 5. Variation of dielectric constant of KDP and KDP with borax as a function of temperature.

\subsection{Electrooptic effect in KDP with nickel phosphate}

The variation of transmitted intensity of light with applied DC voltage across KDP crystals with 0.1 and $0.2 \%$ nickel phosphate (by weight) at various wavelengths and temperatures follows the same trend as shown in figure 2 . The variation of halfwave voltage as a function of wavelength at different temperatures for both the crystals is similar to that of KDP. The half-wave voltages of both the crystals increase with increase in wavelength and temperature as shown in table 3 . In the case of $0.2 \%$ nickel phosphate-doped KDP crystals, the $r_{63}$ coefficients increase with increase in wavelength while those of KDP with $0.1 \%$ nickel phosphate decrease with increase in wavelength, owing to the fact that the percentage dispersion of half-wave voltage in the latter case is higher than that for pure KDP and KDP with $0.2 \%$ nickel phosphate. The half-wave voltages of KDP doped with $0.1 \%$ nickel phosphate were lower than that of KDP. On the other hand, the halfwave voltages of KDP with $0.2 \%$ nickel phosphate were higher than that of pure KDP. These results were confirmed by repeating the experiments many times.

From the results one can conclude that KDP crystals with $0.1 \%$ nickel phosphate have low values of half-wave voltages when compared to those of KDP and KDP with $0.2 \%$ nickel phosphate. This is a significant result because of the reduction of half-wave voltage of KDP with $0.1 \%$ nickel phosphate. This is highly desirable from the device point of view and can be exploited for electrooptic device application. 


\subsection{Electrooptic effect KDP with manganese phosphate}

The variation of transmitted intensity of light as a function of applied DC voltage for KDP doped with $0.025 \%$ manganese phosphate (by weight) at various wavelengths and at different temperatures exhibit a behaviour similar to that of pure KDP which is presented in figure 2. The variation of half-wave voltage as a function of wavelength at different temperatures is similar to that of KDP. The dispersion of the electrooptic coefficient $r_{63}$ with wavelength of light at different temperatures is also similar to that of KDP. The half-wave voltages of these crystals increase with increase in wavelength and temperature as can be seen from table 3 . The electrooptic coefficient $r_{63}$ also increases with increase in wavelength. Further, they decrease with increase in temperature. The half-wave voltages of KDP crystals with $0.025 \%$ manganese phosphate were higher than those of pure KDP crystals.

\subsection{Electrooptic effect in KDP with sodium dihydrogen orthophosphate}

The variation of transmitted intensity with applied DC voltage for KDP doped with $1 \%$ sodium hydrogen orthophosphate (by weight) was similar to that of pure KDP, shown in figure 2. The variation of halfwave voltage as a function of wavelength at different temperatures is also similar to that shown in figure 3 . The dispersion of the electrooptic coefficient $r_{63}$ with wavelength at different temperatures is also similar to that of KDP as shown in figure 4 . The half-wave voltages of KDP with $1 \%$ sodium dihydrogen orthophosphate was higher than those of KDP as shown in table 3 . They increased with increase in wavelength and temperature. Further $r_{63}$ coefficients increased with increase in wavelength and decreased with increase in temperature.

\subsection{Electrooptic effect in KDP with potassium arsenate}

The variation of the intensity of light as a function of applied DC voltage at various temperatures and wavelengths for KDP with $0.5 \%$ potassium arsenate (by weight) is similar to that of KDP. The variation of half-wave voltage as a function of wavelength at different temperatures is similar to that shown in figure 3 . The half-wave voltages of KDP crystals with $0.5 \%$ potassium arsenate were higher than those of KDP as can be seen in table 3 . The most significant aspect of this doping is that the dispersion of halfwave voltage with temperature and wavelength is almost negligible at lower wavelengths.

\section{Conclusions}

In general the half-wave voltages of KDP crystals tend to increase with addition of growth aids such as borax and dopants such as nickel phosphate, manganese phosphate, sodium dihydrogen orthophosphate and potassium arsenate. However, two significant results were obtained. One is the decrease of the half-wave voltage of KDP with addition of $0.1 \%$ nickel phosphate and the other is the temperature insensitivity of dispersion for KDP with $0.5 \%$ potassium arsenate. These results may be very useful in device applications. 


\section{Acknowledgements}

The authors wish to record their appreciation of the valuable discussions they had with

Prof. T S Narasimhamurthy. One of them (KBRV) is thankful to the University Grants Commission, New Delhi for a fellowship.

\section{References}

Kaminow I P and Turner E H 1966 Appl. Opt. 51612

Milek and Neuberger 1972 Handbook of Electronic Materials, (New York: IFI/Plenum) 8

Narasimhamurthy T S, Osmania University, Hyderabad, India - work to be published.

Onaka R and Ito M 1977 Bull. Acad. Sci. USSR Phys. Ser.(USA) 41 59-63

Ramanaiah K V and Varma K B R 1982 Studies on Effects of Additive and Dopants on the

Growth of KDP Crystals - communicated for publication.

Veerabhadra Rao K 1972 Photoelastic and linear electrooptic dispersion in some non cubic crystals Ph.D. Thesis, Osmania University, Hyderabad, India

Vishnevskii and Stefanskii 1972 Handbook of electronic materials, (ed) by Malek and Neuberger,

(New York: IFI/Plenum.)

Vlokh O G et al 1971, Kristallografiya, 16828 